\title{
CULTURAL KEYWORD 'ELING' IN JAVANESE AND ITS IMPLICATION IN JAVANESE SOCIETY
}

\author{
Ounu Zakiy Sukaton ${ }^{1}$ \\ ${ }^{1}$ Universitas Ma Chung, ounu.zakiy@machung.ac.id
}

\begin{abstract}
Cultural keywords are important information that we can use to understand how people who use those words see life from their perspective. The same can be said about the Javanese community. Some of their words and concepts are exclusive to their own and they can give hindsight to how the Javanese people perceive their life. In order to analyse the meaning behind cultural keywords, Natural Semantic Metalanguage (NSM) is used in this article. The data were taken from several social media posts to illustrate the core meaning of the word 'eling'. An explication is proposed for the word 'eling' as well as a brief conclusion about the multiple meaning of 'eling' and its usage.
\end{abstract}

Key Terms: semantics, natural semantic metalanguage, cultural keywords, Javanese language

\section{INTRODUCTION}

The most important key to understanding a culture is to thoroughly examine the words which are used by that particular culture. Wierzbicka (1997, p. 1) argued that "[t]here is a very close link between the life of a society and the lexicon of the language spoken by it". Her view was inspired by the work of Edward Sapir which she quoted in her book. According to Sapir (1949), there are three important links between language and culture:

1. "[L]anguage [is] a symbolic guide to culture" (p. 162)

2. "[V]ocabulary is a very sensitive index of the culture of a people" (p. 27)

3. "[L]inguistics is of strategic importance for the methodology of social science (p. 166)

Sapir's insights are crucial for cultural outsiders who want to study another culture. Without understanding cultural concepts embedded in its language, it is impossible to precisely describe culture-specific concepts.

This article will try to analyse the importance of a cultural keyword 'eling' Javanese society. First, previous studies regarding the word 'eling' will be presented and discussed in section 2. Second, examples of how the word 'eling' is used in modern context will be discussed in section 3. Finally, the proposed explication of the word 'eling' by using Natural Semantic Metalanguage (NSM) will be discussed in Section 4. 


\section{LITERATURE REVIEW}

The first study that we will discuss is written by George Quinn . In his study, Quinn pointed out a number of examples regarding the word 'eling'. One example was taken from a poet named Ranggawarsita (1802-1873) who wrote: Begja-begjane kang lali, isih begja kang eling lan waspada. Quinn's translation was “[h]owever happy those who are lulled into forgetfulness may be, it is always better to be alert and vigilant" (p. 115). 'Eling'was translated into 'alert' and 'waspada' was translated into 'vigilant'. These translations don't really capture the whole meaning of both 'eling' and 'waspada'. The reasons for this argument will be discussed further in section 4. However, the explication and examples of 'waspada' will not be discussed. Moreover, Quinn grouped 'eling', 'waspada', and 'sadhar' together as selfawareness value. He then summarised those three words as "to keep alert and to keep one's guard up" (p.115).

On the other hand, Murtisari argued that the word 'eling' is closely related to the Javanese belief in God. Religion has been a big part of Javanese life since Hinduism was first introduced to the Javanese in the $1^{\text {st }}$ century. In the modern era, Islam has the biggest number of followers and it affects the values hold by modern Javanese. Murtisari believes that most Javanese put God as the centre of life and they were governed by a law called ' $u k u m$ pinesthi' 'law of destiny'. Based on this law, everyone is believed to live a predetermined life and everyone should accept their destiny without being allowed to question their destiny. Murtisari made a connection between the word 'eling', which can be translated as 'remember' when it is used as a verb, and 'ukum pinesthi'. 'Ukum pinesthi' means that everyone should remember that their life is predetermined and they must not stray from the path the has been set up for them. Murtisari proposed an explication of 'eling'based on this notion.

Eling

(a) A person can think something like this

(b) God wants me to live in a certain way

(c) I have to live in this way because of this

(d) It is good to live in this way

(e) If a person can do this all the time, this person will not want something else

(f) this person will not do something bad because of this

(g) It is good if a person thinks like this all the time (p. 118)

What Murtisari failed to capture is the fact that the word 'eling'has multiple meanings. According to Javanese-English Dictionary, 'eling' can mean:

1. To remember/bear in mind

2. To regain consciousness

If we look at Murtisari's explication, we can see that she emphasises the notion that human beings need to bear in mind that their life is predetermined by God. Therefore, not living a life as God had wished will lead to terrible consequences. On the other hand, Quinn translated 'eling' into 'alert' on the basis of the state of alertness after being lulled into forgetfulness. In 
other words, one must regain consciousness (be alert) after being unconscious (lulled into forgetfulness). These two interpretations are not inaccurate considering the fact that the word 'eling'itself has multiple meanings. However, these two interpretations are not accurate either in the modern context for two reasons. First, the implication of 'eling' is not exclusive to religious usage. Second, 'eling' in the context of Quinn's example has no equivalent word in English.

In order to explain 'eling' to cultural outsiders as well as cultural insiders, a cultureindependent tool must be used to avoid misunderstanding. NSM approach is a reliable methodology that we can use to explain culture-specific words to cultural outsiders as well as cultural insiders. "NSM is a reduced language based on a set of sixty-five semantic primes intended to represent the irreducible semantic core shared by all languages." These semantic primes can be combined to form clauses which can be implemented in all languages such as ' $I$ feel something good' and 'someone feels something bad'.

\section{THE USE OF 'ELING' IN THE MODERN CONTEXT}

In order to illustrate the use of 'eling' in modern context, a social media platform called Twitter is used in this study. The reason why Twitter is used is because it's easy to search for posts containing the word 'eling'. There were hundreds of posts came out from Twitter search engine and I picked out some recent posts that contain the word 'eling' which represent either to remember or to regain consciousness in meaning.

\section{To remember/bear in mind}

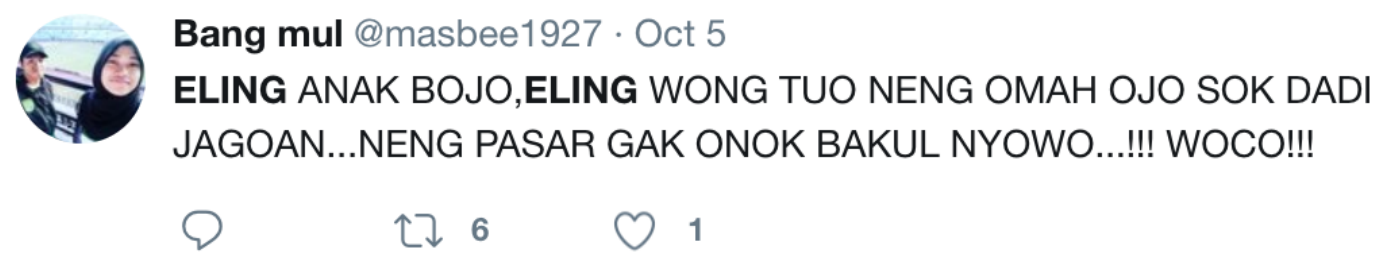

Figure 1.

The example in Figure 1 is roughly translated as "eling (that you have) kid (and) wife, eling (your) parents at home, don't act like a bully... at the market, there's no one selling (extra) life...!!! Read!!!”. This tweet is an angry tweet directed at someone. We can identify this from the use of capital letters throughout the tweet and the number of exclamation marks as well as the threat given at the end of the tweet. In this example, 'eling' would be best translated as 'remember'. However, God is not used in this context and the presence of family members mentioned was used instead to remind someone not to act as he pleases in public. 


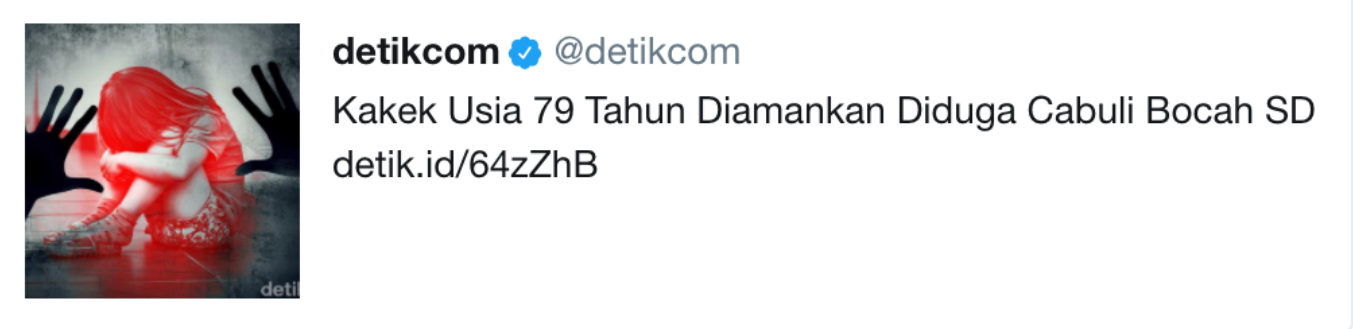

\section{Figure 2.}

The example in Figure 2 is a bit hard to translate because it contains a number of figurative speech such as 'kakean polah' which means someone makes a lot of unnecessary acts that don't really fit his age. The other one is 'mambu lemah' 'smell of soil,' which means someone is close to his death. The rough translation for this example is "FRIDA: Too many acts, eling you smell of soil already grandpa", "detikcom: A 79-year-old grandfather was apprehended for alleged sexual harassment to a primary school kid". The person who posted this tweet was commenting on how the old man should remember that he is already old and he shouldn't have done such thing.

Jean @jeanfstka·Oct 6

Kenapa sih hobi banget barang orang lain dibilang milik pribadi (?) yaaaaaaa ampiun mbiaaaakkk sing eling :(

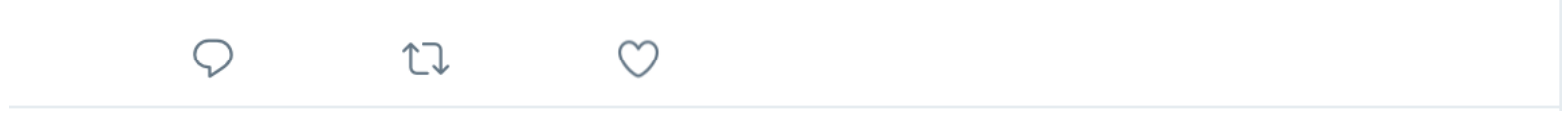

\section{Figure 3.}

The example in Figure 3 is a complaint about someone's behaviour who likes to claim other people things as hers. It is roughly translated as "Why (do you) make a hobby out of claiming other people's things? Oh my god sister (you) have to eling :( ". The use of sister here is actually inaccurate because the poster didn't refer to her female sibling. The term 'mbak' for older female sibling can be used to address women in general. 'Eling' here is used to remind someone that all of the things that she claimed as hers are not actually hers and people know about it. Moreover, the poster used the first sentence in Bahasa Indonesia and the second sentence in Javanese because the second sentence wouldn't make any sense if she had written it in Bahasa Indonesia. 


\section{To regain consciousness}

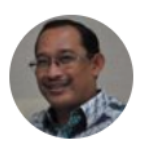

Ratu Adil coming @kurnadi_gularso·Oct 6

Replying to @GusmusQuotes

Jaman Kolobendu. Wolak waliking jaman. Wong sing bejo mung sing eling lan waspodo.

\section{Figure 4.}

The example in Figure 4 is a response to another tweet. However, I was not able to retrieve the tweet that he was referring to. This may affect the interpretation of this example, but his reply is written in general context so I think there should be no problem. This example can be roughly translated as "The age of paradox. The age where everything is upside down. The one who's going to be lucky is the one who's eling and vigilant.". I used the word 'vigilant' to replace 'waspodo' just like Quinn did because we're not going to discuss 'waspodo' further. However, we must note that in this context 'eling' is paired with 'waspodo'.

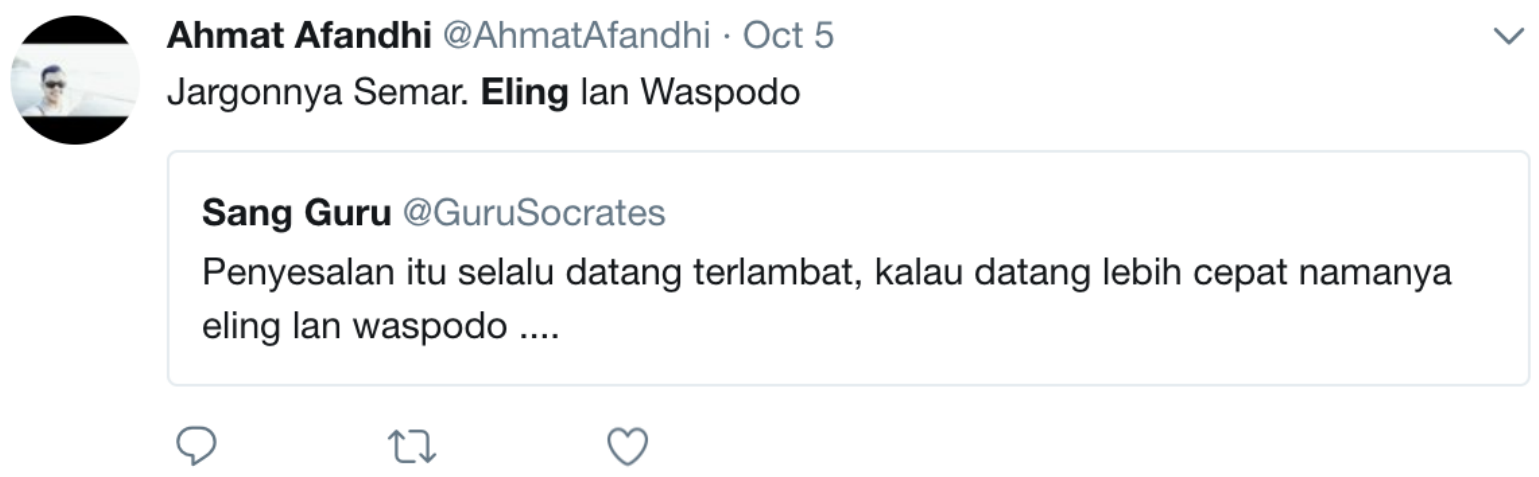

Figure 5.

The example in Figure 5 can be roughly translated as "Ahmat Afandhi: Semar's jargon. Eling and vigilant" "Sang Guru: Regret always comes late, if it came sooner it would be called eling and vigilant". Semar is a wise character in Javanese Wayang Kulit or Shadow Puppets. His most well-known saying is 'eling lan waspada' whenever the king asked for his council. The post from Sang Guru was written in Bahasa Indonesia except for 'eling kan waspodo' part because it is a culture-specific expression. This tweet emphasises the notion that in order to avoid having regret one must stay eling and vigilant constantly. 'Eling' is described as a state that should always appear first before regret. This doesn't mean that if we are in the state of 'eling', regret will follow later. The point is to stay 'eling'all the time so we will have no regret in life. 


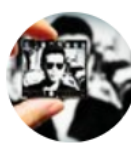

Chirp's SITTO @SittaYohag. Oct 6

Akeh...Durung Mesthi Cukup

Sithik...Durung Mesthi Kurang

Ojo Mburu Seneng

Nanging Mburu'o Ayem

Nrimo Ing Pandum

Tansah Eling Lan Bersyukur

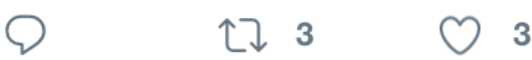

Figure 6.

The example in Figure 6 can be roughly translated as "Plenty... doesn't mean enough. Little ...doesn't mean scarce. Don't strive for happiness. Instead, strive for peace. Be grateful for what you have. Always eling and be grateful. 'Bersyukur' is the only word taken from Bahasa Indonesia in this example. From this example, we can see that the value of 'eling' is embedded by the balance of life and the continuation of the state of consciousness and awareness represented by the word 'tansah' 'always'.

\section{EXPLICATION OF "ELING"}

According to the examples presented in Section 3.1 and 3.2, there are some patterns that we can draw. First, 'eling' is used to ask people to reflect at the things they've done wrong as presented by the examples in Section 3.1. 'Eling' in this context can be replaced by the word 'remember' and it would represent the meaning faithfully. However, the presence of God and predestined way of life is somehow not present in these examples contrary to what Murtisari proposed. Instead, the presence of family members, old age, and behaviour are used as a reminder. Second, 'eling' and 'waspodo' are frequently mentioned together to form an old Javanese saying that can be traced back to Ranggawarsita's poem in Quinn's example. In this context, 'eling' can't be replaced by 'remember' or 'alert' because those two words don't encompass the essence of the word 'eling'. 'Eling' in this context means the state of awareness and the balance in life according to Javanese values represented by the examples in Section 3.2 .

Thus, I propose an explication of the word 'eling' based on the evidence I have provided:

Eling

$\mathrm{X}$ thinks something like this:

When something very good happens to me, I cannot feel very good

When something very bad happens to me, I cannot feel very bad

If I don't think like this, something very bad can happen to me

22 | Cultural Keyword 'Eling' in Javanese and Its Implication in Javanese Society 
Because I think like this, bad things cannot happen to me

I can't not think like this all the time

It is good if someone can think like this all the time

This explication of 'eling' can represent the Javanese values of keeping balance in life. In order to avoid something bad (e.g. regret), constant state of 'eling'should be maintained all the time. If someone can maintain the state of 'eling' all the time, that person may avoid bad things that may happen because of that person recklessness. In this explication, human beings have more control in life and not just surrender to God's will.

\section{CONCLUSION}

'Eling' is a culture-specific word used by Javanese people which has no equivalent word in English when it is used in certain contexts. In order to understand the meaning and usage of 'eling', NSM was used to explicate the semantic meaning of 'eling'. According to the explication given in Section 4, 'eling' is a concept which can be used outside of religious contexts. 'Eling' is a concept where someone must possess self-awareness in order to avoid bad things in life. This word can also be used to encourage someone who is experiencing difficulties in life so that he can push through and face life with positive attitude. However, 'eling' can simply mean 'remember' when used in certain contexts. It is fairly easy to spot which meaning is used when we want to analyse the use of 'eling'. Generally, we can see the meaning of 'remember' when 'eling' is used for everyday communication contexts such as reminding people not to do something. On the other hand, the meaning to regain consciousness' occur when people give advice about life in general. This can be done by using old Javanese proverbs or certain jargons. In this context, the word 'eling' can be commonly found together with the word 'waspada'.

\section{REFERENCES}

Farese, G. M. (2016). "The Cultural Semantics of the Japanese Emotion Terms 'Haji' and 'hazukashii'." New Voices in Japanese Studies, 8, 32-54.

Goddard, C., \& Wierzbicka, A. (2004). "Cultural Scripts: What are They and What Are They Good for." Intercultural pragmatics, 1(2), 153-166.

Gonda, J. (1975). Handbook of Oriental Studies. Section 3 Southeast Asia, Religions, Religionen: Brill.

Murtisari, E. T. (2013). "Some Traditional Javanese Values in NSM: From God to Social Interaction.” International Journal of Indonesian Studies, 1(1), 110-125.

Quinn, G. (1992). The Novel in Javanese: Aspects of Its Social and Literary Character: KITLV Press.

Sapir, E. (1949). "Selected writings of Edward Sapir in language, culture, and personality." In D. G. Mandelbaum (Ed.), Culture, Language and Personality: Selected Essays. Berkeley: University of California Press.

Stuart Robson, D., \& Wibisono, S. (2013). Javanese English Dictionary: Tuttle Publishing.

Wierzbicka, A. (1992).: Semantics, Culture, and Cognition: Universal Human Concepts in Culture-Specific Configurations Oxford University Press. 
Wierzbicka, A. (1997). Understanding Cultures through Their Key Words: English, Russian, Polish, German, and Japanese: Oxford University Press.

Wierzbicka, A. (1999). Emotions Across Languages and Cultures: Diversity and Universals: Cambridge University Press.

Wierzbicka, A. (2014). Imprisoned in English. New York: Oxford University Press.

24 | Cultural Keyword 'Eling’ in Javanese and Its Implication in Javanese Society 